Book Review Symposium "The portability of care in an increasingly mobile world: Chains, drains and circulation"

\title{
Comment 1: Revisiting the gender, migration and development nexus through the 'care circulation' approach
}

\section{Laura Oso}

Universidade da Coruña. ESOMI

laura.oso@udc.es

\begin{abstract}
This symposium offers a critical discussion of the logics and dynamics behind the new 'care circulation' perspective offered by Loretta Baldassar and Laura Merla in their edited volume entitled "Transnational Families, Migration and the Circulation of Care". This contribution revisits some of the major debates on the gender, migration and development nexus, through the lens of the 'circulation of care'.
\end{abstract}

Keywords: transnational families; motherhood; social reproduction; development; circulation of care

Resumen. Comentario 1. Reinterpretando el nexo entre género, migración y desarrollo a través de la lente de la "circulación del cuidado"

Este simposio ofrece una discusión crítica de las lógicas y dinámicas en torno a la nueva perspectiva de la "circulación del cuidado" presentadas por Loretta Baldassar y Laura Merla en su volumen titulado Transnational Families, Migration and the Circulation of Care. Este comentario reinterpreta algunos de los principales debates en torno al nexo entre el género, la migración y el desarrollo, a través de la lente de la «circulación del cuidado».

Palabras clave: familias transnacionales; maternidad; reproducción social; desarrollo; circulación del cuidado 
Firstly, I would like to begin by thanking Loretta Baldassar and Laura Merla for asking me to participate in this inspiring debate on the 'care circulation' multi-dimensional approach of the mobilities of care. I have therefore decided to focus on analysing how this theoretical approach can enrich the gender, migration and development nexus, a topic on which I have been working for the last years alongside my colleague Christine Catarino. For this work I will fundamentally refer to two texts written jointly with this author (Catarino and Oso, 2014; Oso and Catarino, 2014). I will re-examine some of the debates set out in these two texts about the gender, migration and development nexus, considering the 'care circulation approach', defined in the words of Baldassar and Merla as "the reciprocal, multi-directional and asymmetrical exchange of care that fluctuates over the life course within transnational family networks subject to the political, economic, cultural and social context of both sending and receiving societies" (Baldassar and Merla, 2013c:25).

\section{Beyond the economicist perspective on remittances}

Firstly, the studies carried out on the migration-development nexus were traditionally based on considering the financial aspects of remittances, focusing on the analysis of the volume, cost and contribution of remittances to development. They also underestimated the social, cultural and symbolic nature of remittances, with migrating males as the supposed main economic protagonists being the focus of attention of academic works on this topic (Catarino and Oso, 2014). The 'care circulation' approach considers remittances as one of the five types of caregiving or mutual support that are exchanged between family members (economic, accommodation, personal-'hands on', practical, emotional and moral) in line with the conceptualisation of Finch (1989) (Baldassar and Merla, 2013b:12). In this sense, remittances may be analysed according to their relationship with other types of caregiving exchange, which include the social, emotional and moral dimension, thus contributing to going beyond economic analyses of remittances which have traditionally dominated academic debates on the migration-development nexus. It also allows a gender focus that highlights the role of both women and men in the study of remittance circulation.

\section{Exit the confinement of immigrant women in social reproduction}

Secondly, as highlighted by Catarino and Oso, the theoretical approach on the international division of reproductive labour and global care chains, which was fundamentally developed in the nineties, brought to light the importance of considering the role of women in reproduction and care work in the context of globalisation, beyond the economic focus of migrant remittances, highlighting that there is not just economic capital that flows but also immaterial capital. Nonetheless, these works fundamentally focused on studying 'transnational mothers', with the care chains approach thereby being accused "of essentiali- 
sing women by confining them to motherhood" (Catarino and Morokvasic, 2005, quoted by Catarino and Oso, 2014). The 'care circulation' approach enables the role of the different social protagonists in care exchanges to be considered in this process, including men and other generations. This helps migrant women to exit the confinement of the theoretical approach focused on their reproductive role and transnational motherhood.

\section{To break the production/reproduction dyad}

Thirdly, from the 1950s to the turn of the century, the migration-development debate was centred on the production sphere, with men being the protagonists of migration and the main agents of development. Nevertheless, since the turn of the century, the global care chains and transnational motherhood approach, as we have already noted, highlight the role of women as agents in the migration process, focusing on their 'reproductive role', although maintaining the male production/women reproduction dyad in migration debates (Catarino and Oso, 2014). The 'care circulation' approach enables articulating these two spheres (production and reproduction), as the caregiving circulation is understood multidimensionally, including economic exchanges, but focusing on their relationship with personal, social, practical, emotional and moral support exchanges.

\section{Those who stay behind are also agents of development}

Fourthly, the 'care circulation' approach not only brings to light the role of migrants as protagonists, but also that of the different family members that remain in the country of origin and who are equally involved in the 'care circulation' process. Therefore, migrants are not only the sole 'development agents'. The 'care circulation' approach helps to think about the migration-development nexus, considering also those who stay behind as participants in the multi-dimensional exchange of caregiving resources and thus of development.

\section{Beyond 'care circulation' to care as a form of capital that is invested. The impact on social mobility strategies of transnational families and on the development of sending communities}

The 'care circulation' approach has fundamentally centred on bringing to light the exchanges in which transnational families engage. Conceptualisation has focused on highlighting the relational aspect of care. However, less attention has been paid to how the circulation of care, as a resource, has an impact on the quality of life and social mobility trajectories of transnational families. ${ }^{1}$ In

1. The book by Baldassar and Merla (2013a) outlines some works along these lines of analysis (Singh and Cabraal, 2013), even if the theoretical conceptualisation on 'care circulation' outlined in the introduction and chapter 1 of the book (Baldassar and Merla, 2013b and 2013c) place more emphasis on the relational aspect and care exchange. 
this sense, we could delve further into the theoretical conceptualisation, going beyond the relational concept and considering not only the exchange process or circulation of care, but also the forms of investment transnational families have in different care dimensions (economic, accommodation, personal-'hands on', practical, emotional and moral). We could also see the unequal impact these investment forms may have on families' living conditions and on the development of the communities in the country of origin. Beyond its circulation, the study of care could also therefore be considered in its dimension as a resource, or even as a type of capital owned by transnational families (both migrants and those who stay behind). This would enable considering how not only the circulation and distribution, but also the investment process of care, have a complex impact on the quality of life, social mobility trajectories and development of communities in the country of origin. The approach could therefore be strengthened by not focusing solely on the 'care circulation' itself, but also on how the care, as a form of resource or capital, is invested unequally between the members of transnational families, thus having an impact on social mobility trajectories and on development.

In this sense, the work I undertook in Ecuador highlighted how, when explaining social mobility strategies of transnational families and the impact of migration on development, it is necessary to consider the investments in the different forms of capital. In this study, I essentially focused on analysing the dynamics between financial, physical, social and emotional capital, bringing to light the tensions that are produced between these types of resource investments. Beyond thinking in terms of accumulation and capital stock, the work more closely analysed the dynamics of the different capital investments themselves and on how they interact between each other within the framework of migrant social mobility strategies. Households therefore make decisions on capital investments that do not always imply increased benefits or gains on all of them; focusing forces on the accumulation of a certain type of capital may instead imply regression in another. The study also indicates how households negotiate family social-mobility strategies in the transnational space, bringing to the fore the tensions that are produced in these capital investment dynamics between different members of the transnational household: the investment in a type of capital may benefit some members but harm others with regard to quality of life, thus having a differential impact on social mobility trajectories. The work also attempts to reflect on the analytical complexity of understanding capital investment dynamics within the transnational space, highlighting that households may invest in a type of capital in the country of origin, thus causing a negative effect on other capital in the receiving country (Oso, 2011, Oso and Catarino, 2014). These tensions are brought to light in the testimony of Maria, one of my key informants:

My family depends on us $100 \%$. My mother doesn't work, nor does my sister. The youngest, my niece, was born prematurely and we paid for all the hospital costs from here. Now her husband is unemployed after he was dismissed, and 
we have to give them and the child, who is still a baby, money for food. I've just had to send them forty euros because my sister called saying: Can you send me some money for milk? I sometimes get upset, but I say to myself: she doesn't drink milk but the baby must. And of course, I send it to her... [Referring to her mother] My mother says: since you've been over there everybody invites us to parties, everybody pays us attention because if you've got money you can pay for a present. Everybody chooses them as godparents and they're the first to be invited to parties... When my sister got married we paid for the entire wedding, which was the wedding of the century in the district church. Today, people still say that there hasn't been a better one since. Two hundred people. One hundred were just family. All the neighbours in our street came. If we hadn't been here (in Madrid), we wouldn't have been able to have that wedding...And, of course, we did it in style... We spent seven thousand euros...And the following week was my niece's christening... Then we sent her money which wasn't enough because she had to pay off the loan she took out, meaning that what we send her doesn't make ends meet. That's why I say that they have a higher standard of living. We work for others to live...My mother no longer receives public healthcare, she now has a private doctor to treat her ailments. (Maria, daughter of Ms. Magdalena, who migrated alone)

The 'care circulation' approach could therefore be enlarged by not only focusing on the relational aspect or the exchange of care, but also on the consideration of care as a resource or even a form of 'capital that circulates'. This may aid the understanding of the investment dynamics in different resources, which affects various members of the family in different ways and gives rise to the complexity about how the multi-dimensional feature of care is managed between the different social spaces in which migrants live (social space in the country of origin and in the destination country or in the transnational space). This would enable the complexity of the social mobility structures and trajectories to be better understood, as well as the impact of 'care as a form of capital that circulates' in the development of communities in the countries of origin.

\section{Bibliographic references}

Baldassar, Loretta and Merla, Laura (eds.) (2013). Transnational Families, Migration and the Circulation of Care. Understanding Mobility and Absence in Family Life. New York and London: Routledge.

- (2013b). "Introduction: Transnational Family Caregiving Through the Lens of Circulation”. In: BALdAssar, Loretta and Merla, Laura (eds.). Transnational Families, Migration and the Circulation of Care. Understanding Mobility and Absence in Family Life. New York and London: Routledge.

- (2013c). "Locating Transnational Care Circulation in Migration and Family Studies". In: Baldassar, Loretta and Merla, Laura (eds.). Transnational Families, Migration and the Circulation of Care. Understanding Mobility and Absence in Family Life. New York and London: Routledge.

Catarino, Christine and Morokvasic, Mirjana (2005). "Femmes, genre, migration et mobilités”. Revue Européenne des Migrations Internationales, 21 (1), 7-2. <http://dx.doi.org/10.4000/remi.2534> 
Catarino, Christine and Oso, Laura (2014). "The seed and the fertile soil: Re-examining the migration-development nexus based on gender and the interplay between production and reproduction”. In: Guérin, Isabel, GuÉtat-Bernard, Hèléne and Verschuur, Christine (eds.). Under Development: Gender. Hampshire and New York: Palgrave Macmillan.

Oso, Laura and Catarino, Christine (2014). "Rethinking the migration and development nexus: gender insights and the production/reproduction dyad". Paper presented at the XVIII ISA World Congress of Sociology, 13-19 July 2014, Yokohama, Japan.

Oso, Laura (2011). "Plata y/o Amor (2011): Remesas, acumulación de activos y movilidad social de las familias de migrantes ecuatorianas en España”. In: GinieNIEWICZ, Jorge (coord.). La migración latinoamericana a España: una mirada desde el modelo de acumulación de activos. Flacso-GURC: Quito, pp. 129-151.

Singh, Supriya and CabraAl, Anuja (2013). "'Boomerang Remittances' and the Circulation of Care: A Study of Indian Transnational Families in Australia”. In: Baldassar, Loretta and Merla, Laura (eds.). Transnational Families, Migration and the Circulation of Care. Understanding Mobility and Absence in Family Life. New York and London: Routledge. 